\title{
ASSESSMENT OF COMBINED EFFECT OF HUMAN FECES COMPOST AND SINGLE SUPERPHOSPHATE ON THE BEHAVIOUR OF WHEAT PRODUCTION
}

\author{
A. JAMAL ${ }^{1 *}$, M. FAWAD ${ }^{2}$ \\ *E-mail: aftabses98@gmail.com
}

Received: Sept. 02, 2019. Revised: Oct. 28, 2019. Accepted: Nov. 05 , 2019. Published online: Dec. 20, 2019

\begin{abstract}
Application of organic fertilizers in improving soil fertility has become a major factor that has enabled the world to feed billions of people. However, the required quantities of organic material are enormous, so it becomes necessary to combine different types of fertilizers to feed plants. The effectiveness of human feces compost (HC) alone, as well as in combination with single super phosphate (SSP), was evaluated in the present study. A field experiment was conducted at farmer field located in district Swabi (Pakistan).
\end{abstract} A total of eight possible treatments combination were arranged in randomized complete block design (RCBD), replicated four times. Two levels of human feces compost (HC), including control ( $\mathrm{HC} 0$ : control and $\mathrm{HC} 1: 7.5 \mathrm{t} \mathrm{ha}^{-1}$ ) and four levels of $\mathrm{P}$, as single superphosphate (SSP), including control (P0: control, P1:40 kg ha ${ }^{-1}, \mathrm{P} 2: 60 \mathrm{~kg} \mathrm{ha}^{-1}$ and P3: $90 \mathrm{~kg} \mathrm{ha}^{-1}$ ) were utilized in the experiment. Results revealed that among all the treatments, combined application of SSP at $60 \mathrm{~kg} \mathrm{ha}^{-1}$ along with $7.5 \mathrm{t} \mathrm{ha}^{-1}$
HC significantly improved the growth, as well as the yield parameters of wheat crop. These results allow saving a half of usually made mineral fertilizer dose for the cultivation of wheat crop. Combined use of $\mathrm{HC}$ and SSP were strongly recommended for obtaining maximum wheat yield in the prevailing soil and environmental conditions.

Keywords: phosphorous; Swabi; calcareous soil; wheat.

\section{INTRODUCTION}

Continuous use of inorganic fertilizers and no use of organic fertilizers is becoming a serious threat to soil fertility in Pakistan, and that might be the big reason of low wheat production, as compared to the developing countries (Jamal and Fawad, 2018). In recent modern era, agricultural scientists have a keen interest to develop an agricultural system, which can lower production

\footnotetext{
${ }^{1}$ Department of Soil and Environmental Sciences University of Agriculture Peshawar, Pakistan

2 Department of Weed Sciences University of Agriculture Peshawar, Pakistan
} 


\section{EFFECT OF HUMAN FECES COMPOST AND SINGLE SUPERPHOSPHATE ON WHEAT}

cost and conserve the natural resources. Therefore, recent interest in application of organic fertilizers has reemerged because of high prices of inorganic fertilizers and the importance of organic fertilizers that provide long term soil productivity, as well as provides almost all essential nutrients to crops and in return increased productivity (Abas et al., 2012). Pakistani soils are generally low in organic matter content $(<1 \%)$ because of arid climate and addition of less organic matter to soils during cultivation (Jamal and Jamal 2018). Soil fertility can be increased with addition of organic matter and utilization of minerals (Azad et al., 1982) and in combination render greater beneficial effects on plant growth and yield (Channabasanagowda et al., 2008). The use of organic manures, like composts, animal manure, as well as human waste, may be a positive and significant step in improving soil fertility, as it restores of the exhausted nutrients from the soil (Jamal and Fawad, 2018). Organic materials not only improve soil health, but also play a key role in phyto-availability of the nutrients by increasing organic matter contents in the soil and improving the soil texture (Alam et al., 2003).

Human excreta can be used as fertilizer for growing crops because it contains many essential macro, as well as micro nutrients (HeinonenTanski and Van Wijk-Sijbesma, 2005). The beneficial effect of human excreta for crop growth has the subject of numerous researchers.
Schouw et al. (2002) reported that human excreta is the best and major source of macro as well as micro nutrients. Similarly, Guzha et al. (2005) studied human fecal matter as a fertilizer and reported an improvement in maize yield, as well as in soil fertility with application of human excreta. The developed countries, like China and Japan, frequently used human excreta as night soils, without any hesitation for agricultural productivity. However, poor handling of human excreta has been reported by Xu et al. (1995) and (Humphries et al., 1997).

It has been reported by many researchers that human excreta can be used as organic fertilizers because it provides appropriate amount of nitrogen $(\mathrm{N})$, phosphorous $(\mathrm{P})$, as well as potassium $(\mathrm{K})$ for growing crops (Mnkeni and Austin, 2009; Kutu et al., 2011), beside that human faeces also provide organic matter to the soil, which in turn improve soil structure (Jönsson et al., 2004). Reuse of human excreta will reduce the pollution effects that result from unsafe excreta disposal and excess use of chemical fertilizers and protect surface and groundwater, as well as waterborne enteric microbiological diseases (Heinonen-Tanski and Wijk-Sijbesma, 2005).

Before using human waste as a fertilizer, they must be composted, as the number of enteric bacteria, viruses, protozoa and helminthes eggs in faeces can be high. Keeping in view the importance of human fecal compost for agricultural crops, the 


\section{A. JAMAL, M. FAWAD}

present study was organized on calcareous soil of Swabi (Pakistan) to evaluate the effect of human feces compost in combination with single super phosphate (SSP) on wheat crop yield.

\section{MATERIAL AND METHODS}

\section{Experimental site description}

The present study was conducted at farmer field at village Yar Hussain (Swabi), located at $34^{\circ} 10^{\prime} 19^{\prime \prime} \mathrm{N}$ and $72^{\circ} 16^{\prime} 19$ E of Khyber PakhtunKhwa, Pakistan, with an elevation of $295 \mathrm{~m}$ above the sea level, during 2017-18.

\section{Human fecal source and composting process}

Human fecal used to prepare the compost were collected from camp area, an informal settlement in experimental area Swabi. The fecal were collected in biodegradable bags that are single use toilets and used once by one person. Fecal compost was prepared by using pit method (Mengistuet al., 2017 and Violet, 2015). A total of four pits were prepared for composting purpose, each measuring 2 $\mathrm{m}$ long by $2 \mathrm{~m}$ wide and $0.5 \mathrm{~m}$ deep. Biodegradable bags containing human feces were then laid in two layers and covered by a thin layer of soil. After three weeks, the contents were then transferred into another pit and to the third pit where it was allowed to cure for a month after which it was uncovered and packed in big bags ready for use.

\section{Experimental design and treatments}

Two levels of human fecal compost (HC), including control ( $\mathrm{HC} 0$ : control and $\mathrm{HC1}$ : $7.5 \mathrm{t} \mathrm{ha}^{-1}$ ) and four levels of $\mathrm{P}$ as single super phosphate (SSP), including control (P0: control, P1:40 $\mathrm{kg} \mathrm{ha}^{-1}, \mathrm{P} 2$ : $60 \mathrm{~kg} \mathrm{ha}^{-1}$ and P3: $90 \mathrm{~kg} \mathrm{ha}^{-1}$ ) were utilized in the experiment. Eight possible treatments combination were arranged in RCBD, replicated four times. Each plot size was kept to $20 \mathrm{~m}^{2}$; all the treatments were applied before seed sowing. Wheat variety Pirsabak 2013 was used as test crop and was sown with seed rate of 120 $\mathrm{kg}$ seed $\mathrm{ha}^{-1}$ and maintained row to row distance of $25 \mathrm{~cm}$. All the agronomic and cultural practices were maintained during the experiment. At maturity, the growth parameters, like plant height and spike length $(\mathrm{cm})$, were recorded, while yield parameters, like 1000-grain weight, grain yield and biological yield ( $\mathrm{t} \mathrm{ha} \mathrm{h}^{-1}$, were recorded after crop harvest.

Following treatments combination was utilized during the study: Treatment 1 - P0HC0; Treatment 2 - P0HC1; Treatment 3 - P1HC0; Treatment 4 $\mathrm{P} 1 \mathrm{HC} 1$;reatment 5 - $\mathrm{P} 2 \mathrm{HC} 0$; Treatment 6 - $\mathrm{P} 2 \mathrm{HC} 1$; Treatment 7 P3HC0; Treatment 8 - P3HC1.

\section{Physico-chemical properties of soil}

A composite soil sample was taken $(0-20 \mathrm{~cm}$ depth) from the field before treatments application and was analyzed for various physical and chemical properties, like pH, EC (Richards, 1954), soil texture (Gee and Bauder 1986), lime content (U.S. Salinity Laboratory Staff. 1954), and organic matter (OM) (Nelson and Sommer, 1982). The soil was also analyzed for total N (Bremner, 1996), AB-DTPA-extractable $\mathrm{P}$ and $\mathrm{K}$ (Soltanpour, 1985). The soil under study was found highly calcareous in nature, alkaline in reaction with $\mathrm{pH}$ value (8.0), EC (1.5), low in organic matter content (0.59) and silty clay loam in texture. The available total $\mathrm{N} 0.04 \%$, available P 3.9 $\mathrm{mg} \mathrm{kg}^{-1}$ and exchangeable $\mathrm{K} 130 \mathrm{mg} \mathrm{kg}^{-1}$ were recorded, respectively (Table 1). Soil of district Swabi was found low in OM content, as reported by Jamal and Jamal (2018). 


\begin{tabular}{|c|c|}
\hline Property & Value \\
\hline Clay (\%) & 19 \\
\hline Silt (\%) & 62 \\
\hline Sand $(\%)$ & 19 \\
\hline Textural class & $\begin{array}{c}\text { Silty clay } \\
\text { loam (SCL) }\end{array}$ \\
\hline pH (1:5; Soil: Water) & 8.0 \\
\hline Organic matter (\%) & 0.59 \\
\hline$E C\left(d_{s m}^{-1}\right)$ & 1.5 \\
\hline Lime $\left(\mathrm{CaCO}_{3}\right)(\%)$ & 16.8 \\
\hline AB-DTPA P $\left(\mathrm{mg} \mathrm{kg}^{-1}\right)$ & 3.9 \\
\hline Total N (\%) & 0.04 \\
\hline AB-DTPA K $\left(\mathrm{mg} \mathrm{kg}^{-1}\right)$ & 130 \\
\hline
\end{tabular}

\section{Statistical analysis}

Using Statistix, 2000 package and Least Significant Difference (LSD) test, the collected data were analyzed statistically for any significant difference among the treatments (Steel and Torri, 1981).

\section{RESULTS AND DISCUSSION}

\section{Plant height (cm)}

The overall result of different treatments on wheat plant height was found non-significant at $p<0.05$ (Table 2). Many researchers reported significant increase in wheat plant height with application of $\mathrm{P}$, as well as organic fertilizers in the prevailing soil and environmental conditions (Jamal and Fawad 2018, Naseer and Muhammad, 2014). The nonsignificant effect might be due to marginal AB-DTPA extractable P (3.9 $\mathrm{mg} \mathrm{kg}^{-1}$ ), in addition the $\mathrm{P}$ is known to more contribute in yielding components, like flower, seed formation and ripening rather than crop growth.

\section{Spike length}

Application of human fecal compost alone and in combination with single superphosphate significantly increased the wheat spike length, as compared with control treatment (Table 2). The maximum spike length of $8.62 \mathrm{~cm}$ was recorded at $\mathrm{T} 6$, where $\mathrm{P}$ was applied at $60 \mathrm{~kg} \mathrm{ha}^{-1}$ in combination with human fecal compost at $7.5 \mathrm{t} \mathrm{ha}^{-1}$ (Table 2). However, the values of spike length at T6, T7 and T8 were found statistically similar with each other, indicated that possibly $60 \mathrm{~kg} \mathrm{ha}^{-1}$ in combination with human fecal compost at $7.5 \mathrm{t} \mathrm{ha}^{-1}$ could be the optimum level under the given soil and climatic conditions. Our results were in lined with Jamal and Fawad (2018) and Ahmad et al. (2013); they also reported an increased in wheat spike length with the application of organic and inorganic fertilizers.

\section{0-grain weight}

Application of different treatments significantly increased wheat 1000-grain weight. The maximum 1000-grain weight of $45 \mathrm{~g}$ was recorded at $\mathrm{T} 8$, where $\mathrm{P}$ was applied at rate of $90 \mathrm{~kg} \mathrm{ha}^{-1}$ with $\mathrm{HC}$ at rate of $7.5 \mathrm{t} \mathrm{ha}^{-1}$ (Table 2). However, this highest 1000-grain weight was statistically similar and closely followed by T6 with value of $44.7 \mathrm{~g}$, where $\mathrm{P}$ was applied in combination with $\mathrm{HC}$ at $60 \mathrm{~kg} \mathrm{ha}^{-1}$ and $7.5 \mathrm{t} \mathrm{ha}^{-1}$, respectively.

Our results were in agreement with Ahmad et al. (2013), Jamal and Fawad (2018), Akhtar et al. (2000) and Jamal et al. (2019); they reported 


\section{A. JAMAL, M. FAWAD}

that organic fertilizers in combination with chemical fertilizers significantly improved yield contributing factors in wheat crop, as compared with chemical fertilizers applied alone.

\section{Biological yield}

The data on biological yield of wheat responded significantly to different applied treatments. Biological yield of wheat was significantly increased from 4.65 at $\mathrm{T} 1$ (control) to $13.2 \mathrm{t} \mathrm{ha}^{-1}$ at T6, where $\mathrm{P}$ was applied in combination with $\mathrm{HC}$ at $60 \mathrm{~kg} \mathrm{ha}^{-1}$ and $7.5 \mathrm{t} \mathrm{ha}^{-1}$, respectively (Table 2). These values suggested that $60 \mathrm{~kg} \mathrm{ha}^{-1} \mathrm{P}$ along with $\mathrm{HC}$ at $7.5 \mathrm{t} \mathrm{ha}^{-1}$ could be the optimum levels to avoid the luxury consumption by crop and extra input by farmers. Our result was also in lined with the findings of Ghosh et al. (2004) and Sarwar et al. (2007). The significant effect of organic and chemical fertilizers in combination for wheat crop was also reported by
Jamal and Fawad (2018) and Jamal et al. (2019) for the same soil and environmental conditions.

\section{Grain yield}

Wheat grain yield was significantly increased with the application of SSP and HC, either applied alone or in combination, as compared with the control treatment. The maximum grain yield of $4.82 \mathrm{tha}^{-1}$ was recorded in $\mathrm{T} 6$, where $\mathrm{P}$ was applied in combination with $\mathrm{HC}$ at $60 \mathrm{~kg} \mathrm{ha}^{-1}$ and $7.5 \mathrm{t} \mathrm{ha}^{-1}$, respectively (Table 2). The increase in grain yield is in consistency of many research reports. Ahmad et al. (2013) revealed that yield in high lime was low, which gradually increased with $\mathrm{P}$ application along with organic fertilizers. Similarly, Patil et al. (2000) reported maximum grain yield with application of organic fertilizers. Our results were also in lined with the findings of Abbas et al. (2012), Jamal et al. (2019) and Jamal and Fawad (2018).

Table 2 - Effect of different levels of SSP alone and in combination with HC on plant height, spike length, 1000-grain weight, grain yield and biological yield of wheat

\begin{tabular}{|c|c|c|c|c|c|}
\hline Treatments & $\begin{array}{l}\text { Plant } \\
\text { height } \\
\text { (cm) }\end{array}$ & $\begin{array}{l}\text { Spike } \\
\text { length } \\
\text { (cm) }\end{array}$ & $\begin{array}{l}1000 \text {-grain } \\
\text { weight }(\mathrm{g})\end{array}$ & $\begin{array}{l}\text { Biological } \\
\left.\text { yield (t ha }{ }^{-1}\right)\end{array}$ & $\begin{array}{l}\text { Grain } \\
\text { yield } \\
\text { (t ha-1) }\end{array}$ \\
\hline $\mathrm{T} 1=\mathrm{P} 0 \mathrm{HCO}$ & $75.250 a$ & $7.9450 d$ & $32.250 \mathrm{~g}$ & $4.650 \mathrm{e}$ & $2.1325 \mathrm{e}$ \\
\hline $\mathrm{T} 2=\mathrm{P} 0 \mathrm{HC} 1$ & $75.250 a$ & $8.0500 \mathrm{~cd}$ & $34.000 f$ & $5.350 \mathrm{e}$ & $2.9000 \mathrm{~d}$ \\
\hline $\mathrm{T} 3=\mathrm{P} 1 \mathrm{HCO}$ & $76.250 a$ & $8.1250 \mathrm{~cd}$ & $36.000 \mathrm{e}$ & $6.325 d$ & $3.1000 \mathrm{~d}$ \\
\hline $\mathrm{T} 4=\mathrm{P} 1 \mathrm{HC} 1$ & $75.000 a$ & $8.2500 \mathrm{bc}$ & $37.750 d$ & $8.475 c$ & $3.6750 \mathrm{c}$ \\
\hline $\mathrm{T} 5=\mathrm{P} 2 \mathrm{HCO}$ & $75.500 a$ & $8.3250 \mathrm{bc}$ & $39.500 c$ & $9.175 c$ & $3.7750 c$ \\
\hline $\mathrm{T} 6=\mathrm{P} 2 \mathrm{HC} 1$ & $76.250 a$ & $8.6250 a$ & $44.750 a$ & $13.200 a$ & $4.8250 a$ \\
\hline $\mathrm{T} 7=\mathrm{P} 3 \mathrm{HCO}$ & $75.250 a$ & $8.6250 a$ & $42.000 \mathrm{~b}$ & $11.500 \mathrm{~b}$ & $3.9500 \mathrm{c}$ \\
\hline $\mathrm{T} 8=\mathrm{P} 3 \mathrm{HC} 1$ & $76.000 a$ & $8.6250 a$ & $45.000 \mathrm{a}$ & $12.500 \mathrm{a}$ & $4.3250 \mathrm{~b}$ \\
\hline $\operatorname{LSD}_{(0.05)}$ & NS & 0.2891 & 1.3767 & 0.7967 & 0.3495 \\
\hline
\end{tabular}

${ }^{*} \mathrm{P}(\mathrm{P} 0, \mathrm{P} 1, \mathrm{P} 2$ and $\mathrm{P} 3): \mathrm{P}_{2} \mathrm{O}_{5}$ levels (control, 40, 60 and $90 \mathrm{~kg} \mathrm{ha}^{-1}$ ) and $\mathrm{HC}(\mathrm{HC} 0$ and $\mathrm{HC}$ 1): Human fecal compost levels (control and $7.5 \mathrm{t} \mathrm{ha}^{-1}$ ); ${ }^{* *}$ Means with different letter (s) in columns are significantly different at $p<0.05$. 


\section{CONCLUSIONS}

It was concluded from the results that the effect of $\mathrm{HC}$ on wheat yield is more pronounced at low level of SSP, as compared to higher levels. Furthermore, it was concluded that $60 \mathrm{~kg} \mathrm{ha}^{-1} \mathrm{P}$ along with $7.5 \mathrm{t} \mathrm{ha}^{-1} \mathrm{HC}$ was more effective and could be the optimum level for wheat crop in the prevailing soil and environmental conditions. Further researches were strongly recommended for widespread recommendations.

\section{REFERENCES}

Abbas, G., Khattak, J.Z.K., Mir, A., Ishaque, M., Hussain, M., Wahedi, H.M., Ahmed, M.S. \& Ullah, A. (2012). Effect of organic manures with recommended dose of NPK on the performance of wheat (Triticum aestivum L.) J.Anim.Plant.Sci, 22(3), 683-687.

Ahmad, M., Afzal, M., Ahmad, A., Ahmad, A.U.H. \& Azeem, M.I. (2013). Role of organic and inorganic nutrient sources in improving wheat crop production. Cercet.Agron. in Moldova, 46(1), 1521, DOI: 10.2478/v10298-012-00710

Akhtar, Z., Ali, A., Akhtar, T. \& Yousaf, M. (2000). Comparative effect of phosphate fertilizer and farmyard manure on Kohistan-97. In: Proc. Symp. "Integrated Plant Nutrition Management" NFDC, Islamabad, pp. 196-201.

Alam S.M., Shah, S.A., Ali, S. \& Iqbal, M.M. (2003). Effect of integrated use of industrial wastes and chemical fertilizer on phosphorus uptake and crop yields. Pak.J.Soil Sci., 22: 81-86.
Azad, M.I. \& Yousaf, M.V. (1982). Recycling of organic matter to improve the soil productivity. Pakistan J.Agric.Res., 22: 15-18.

Bremner, J.M. (1996). Nitrogen-total. In: Sparks, D.L. (Ed.), Methods of Soil Analysis, Part 3: Chemical Methods, SSSA Book Series 5, SSSA, Madison, Wisconsin, 1085-1122.

Channabasanagowda, N.K., Patil, B., Patil, B.N., Awaknavar, J.S., Ninganurn, B.T. \& Hunje, R. (2008). Effect of organic manures on growth, seed yield and quality of wheat. Karnataka J.Agric.Sci., 21(3): 366-368.

Gee, G.W. \& Bauder, J.W. (1986). Particle-size analysis. In: Klute, A. (Ed.), Methods of Soil Analysis, Part 1, 2nd Ed., Physical and Mineralogical Methods, ASA/SSSA, Book Series 5.1, Madison, WI, 383411, DOI:10.2136/sssabookser5.1.2 ed.frontmatter

Ghosh, P.K., Bandyopadhyay, K.K., Manna, M.C., Mandal, K.G., Misra, A.K. \& Hati, K.M. (2004). Comparative effectiveness of cattle manure, poultry manure, phosphocompost and fertilizer-NPK on three cropping systems in vertisols of semi-arid tropics. II. Dry matter yield, nodulation, chlorophyll content and enzyme activity. Bioresour.Technol., 95(1), 85-93, DOI: 10.1016/j.biortech.2004.02.012

Guzha, E., Nhapi, I. \& Rockstrom, J. (2005). An assessment of the effect of human faeces and urine on maize production and water productivity. Phys. Chem.Earth, $30(11-16)$ : 840-845.

Heinonen-Tanski, H. \& Van WijkSijbesma, C. (2005). Human excreta for plant production. Bioresour.Technol., 96(4): 403-411, DOI: 10.1016/j.biortech.2003.10.036

Humphries, D.L., Stephenson, L.S. Pearce, E.J., The, P.H., Dan, H.T. \& Khanh, L.T. (1997). The use of human faeces for fertilizer is 


\section{A. JAMAL, M. FAWAD}

associated with increased intensity of hookworm infection in Vietnamese women. Trans.R.Soc.Trop.Med.Hyg. 91(5): 518-520, DOI: 10.1016/S00 35-9203(97)90007-9

Jamal, A. \& Fawad, M. (2018). Application of different organic manures in optimizing optimum yield for wheat in calcareous soil. World News of Natural Sciences, 20: 23-30.

Jamal, A. \& Jamal, H. (2018). Assessment and Distribution of Macro and Micro Nutrients in Different Soil Series of District Swabi, Khyber Pakhtunkhwa, Pakistan. JHPR, 2: 23-32, DOI: 10.18052/www.scipress.com/JHPR. 2.23

Jamal, A., Younas, W. \& Fawad, M. (2019). Performance of wheat (Triticum aestium L.) as influenced by application of single super phosphate alone and in combination with different organic fertilizers in calcareous soil of Swabi, Pakistan. KSÜ Tarım ve DoğaDerg., 22(1): 14-18, DOI:10.18016/ksutarimdoga. v22i39650.455876

Jönsson, H., Stintzing, A.R., Vinnerås, B. \& Salomon, E. (2004). Guidelines on the use of urine and faeces in crop production. Stockholm: Stockholm Environment Institute. EcoSanRes publications series, 2004-2, ISSN 91-88714-94-2

Kutu, F.R., Muchaonyerwa, P. \& Mnkeni, P.N. (2011). Complementary nutrient effects of separately collected human faeces and urine on the yield and nutrient uptake of spinach (Spinacia oleracea). Waste Manage.Res., 29(5): 532-539.

Mengistu, T., Gebrekidan, H., Kibret, K., Woldetsadik, K., Shimelis, B. \& Yadav, H. (2017). Comparative effectiveness of different composting methods on the stabilization, maturation and sanitization of municipal organic solid wastes and dried faecal sludge mixtures.
Environ.Syst.Res., 6: 5, DOI: 10.1186/s40068-017-0079-4

Mnkeni, P.N.S. \& Austin, L.M. (2009). Fertiliser value of human manure from pilot urine-diversion toilets. Water SA, 35(1), DOI: 10.4314/ wsa.v35i1.76717

Naseer, M. \& Muhammad, D. (2014). Direct and residual effect of hazara rock phosphate (HRP) on wheat and succeeding maize in alkaline calcareous soils. Pak.J.Bot, 46(5), 1755-1761.

Nelson, D.W. \& Sommer, L.E. (1982). Total carbon, organic carbon and organic matter. In A.L. Page., R. H. Miller and D. R. Keeny (Eds.), Methods of Soil Analysis, Part 2, $2^{\text {nd }}$ Ed., Agronomy Monograph, No. 9, ASA and SSSA, Madison, 539-579.

Patil, V.S. \& Bhilare, R L. (2000). Effect of vermicompost prepared from different organic sources on growth and yield of wheat. J. Maharashtra Agric.Univ., 25(3): 305-306.

Richard, L.A. (1954). Diagnosis and improvement of Saline and Alkali soils. USDA, Agriculture Handbook, No. 60.

Sarwar, G., Hussain, N., Schmeisky, H. \& Muhammad, S. (2007). Use of compost an environment friendly technology for enhancing rice-wheat production in Pakistan. Pak.J.Bot., 39(5): 1553-1558.

Schouw, N. L., Danteravanich, S., Mosbæk, H. \& Tjell, J.C. (2002). Composition of human excreta - a case study from Southern Thailand. Sci.Total Environ., 286(1-3): 155166, DOI: 10.1016/S0048-9697(01) 00973-1

Soltanpour, P.N. \& Schwab, A.P. (1985). A new soil test for simultaneous extraction of macro- and micronutrients in alkaline soils. Comm. Soil Sci. Plant Anal., 8(3): 195-207, DOI: 10.1080/00103627709366714

Steel, R.G.D. \& Torrie, J. (1981). Principles and procedures of statistics. A biometric approach. 2nd 


\section{EFFECT OF HUMAN FECES COMPOST AND SINGLE SUPERPHOSPHATE ON WHEAT}

Ed., Mc Graw Hill International Book Co., Singapore City.

U.S. Salinity Laboratory Staff. (1954). Carbonate and bicarbonate by titration with acid. In: L.A. Richards (Ed.), Diagnosis and improvement of saline and alkali soils. USDA, Agricultural Handbook, No. 60, p. 98, U.S. Government Printing Office, Washington, D.C. USA.

Violet, N.K. (2015). Evaluating the agronomic effectiveness of human faecal compost on maize yields, its influence on soil chemical properties and soil fauna abundance. Doctoral dissertation, University of Nairobi.

Xu, L.Q., Yu, S.H., Jiang, Z.X., Yang, J.L., Lai, L.Q., Zhang, X.J. \& Zheng, C.Q. (1995). Soil-transmitted helminthiases: nationwide survey in China. Bull World Health Organ., 73(4): 507-513 